\title{
Planning and Cost Analysis of Washing Porang Subber on Combination Machine for Washing and Cutting Porang Tuber
}

\author{
Liza Rusdiyana $^{1 *}$, Nanda Ela Sasmita ${ }^{1}$, Nur Husodo ${ }^{1}$, Eddy Widiyono ${ }^{1}$, M Lukman Hakim $^{1}$, Rizaldy \\ Hakim $^{1}$
}

\begin{abstract}
The cleaning process plays an important role in producing hygienic porang tubers, so that later chips and porang flour have good quality. Currently, the home industry for processing porang tubers still uses a simple method, namely using a manual washing machine so that it requires a lot of energy and a long time. One alternative to increase efficiency and productivity is to make a porang tuber washing machine. In planning this machine, it begins with field studies and literature. Planning in designing this machine includes planning for motor power, shaft, bearing, pulley-belt, sprocket-chain and budget design, after calculating and getting results it is necessary to conduct experiments to get conclusions from this machine. In planning the calculation of the machine, it requires a motor power of $2.2 \mathrm{HP}$ with a motor rotation of $1400 \mathrm{rpm}$ and a shaft rotation of $35 \mathrm{rpm}$, a force of $25.6 \mathrm{~N}$, a torque of $1.920 \mathrm{~N}$.mm, the selling price of the tool is Rp. 15,970,000 and the payback period is achieved in 228.4 days or 28.5 weeks or 7.1 months.
\end{abstract}

Keywords : Porang tubers, Machine, Cleaning, Efficiency

\section{INTRODUCTION}

$\mathrm{P}$ orang tuber (Amorphophallus Muelleri Blume) belongs to the Araceae family, was a type of tuber plant that has potential and prospects to be developed in Indonesia. Besides being easy to obtain, this plant was also able to produce carbohydrates, fats, proteins, minerals, vitamins, and dietary fiber. Porang tubers have the potential to have high economic value, because they contained glucomannan which was good for health and can be easily processed into food to meet daily needs. Processing porang tubers into chips or flour could add value to the porang tubers. If porang tubers was priced at Rp. 8,000-11,000 per kg, then porang chips was priced at around Rp. 65,000 -85,000 per kg, and the price of porang flour could reach Rp. 200,000 - 500,000 per kg [1].

According to the growing opportunity for porang tuber cultivation, Indonesian farmers, especially in East Java such as Jember, Nganjuk, Saradan, Padangan, Bojonegoro, Madiun were competing to plant porang tubers [2]. Technological developments made it easier for farmers to wash and slice porang tubers, so that farmers no longer do the work manually.

From the problems faced by the porang tuber farmers, they needed tools that can minimize time and costs. In this study, the author took the theme "Planning and Cost Analysis of Washing Porang Bulbs on a Combination Machine for Washing and Cutting Porang Bulbs".

Based on some of the background that has been described above, the authors get several problem formulations, namely: How much force and torque is needed in the washing process of porang tubers; How much power does the motor use to wash porang tubers; How much is the budget plan used to make a porang tuber washing machine?
These experiments aimed to study the effect of the amount of baker's yeast and tape yeast on the production of ethanol in the fermentation; and the effect of the sugar content of sap sugarcane wastewater on ethanol production

\section{METHOD}

\section{A. Porang tuber process mechanism}

The components that make up the porang washing machine consist of a gasoline motor, bearing, gearbox, vbelt, pulley, chain, sprocket, and shaft. The research method begins with field observations and literature studies. From observations in the field, the problems that have been described previously were obtained. At the observation stage, what needs to be considered is the time used in the porang washing process and the capacity in 1 porang washing cycle. Based on the data in this field, it is known what components need to be studied during the literature study. The first step is to start planning the engine components, starting from the engine power of the motor used, the rotational speed of the shaft, the rotation speed of the motor and the gearbox. Followed by the calculations to support the analysis carried out. The calculations include: analysis of force and torque, planning of belts and pulleys, planning of sprockets and chains, planning of shafts and bearings as well as analysis of calculating the selling price of tools and BEP. After these analyses are carried out, the next step is to assemble the existing components. When the component assembly has been completed, it is started to evaluate whether the designed machine is according to plan or not. If it is according to plan, the research will continue with report writing. But if it does not go according to plan, then return to the component calculation stage. Analyse which parts are considered not in accordance with what is in the field.

\footnotetext{
1 Department of Industrial Mechanical Engineering, Faculty of Vocational Studies, Institut Teknologi Sepuluh Nopember, Kampus ITS, Sukolilo, Surabaya, 60111. Email: $\underline{\text { liza@me.its.ac.id }}$
} 
Cleaning was the process of removing dirt attached to the porang tubers [3]. The goal was to remove dirt that sticks to the porang tubers, such as soil, plant residues or plant roots so as not to reduce the quality of the porang tuber chips later [4]. To wash it by putting the porang tubers into the washing machine. This designed porang tuber washing machine could be used to clean the porang tuber skin by using a brush that has a smooth texture on the inside of the porang tuber washing cylinder and the design of the water reservoir to be designed in a cylindrical shape. The specifications of the porang tuber washing machine based on this calculation have an overall length of $1550 \mathrm{~mm}$, a width of $1070 \mathrm{~mm}$, a height of $1400 \mathrm{~mm}$. It shown to Figure 1.

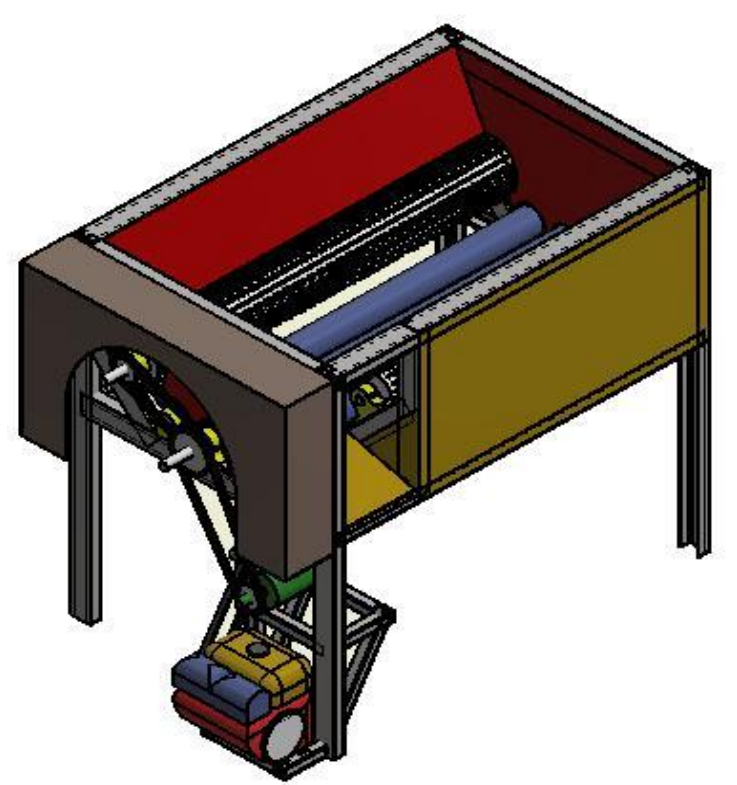

Figure 1. Porang tuber machine

The working mechanism of this porang tuber washing machine uses 2 brushes and 3 shafts, but only the center rotates. When the crank is installed in the crankcase, the motor is rotated with sufficient power, the motor which has a power of $2.2 \mathrm{HP}$, with a rotation of $1400 \mathrm{rpm}$ will turn on [4]. When the motor is turned on, the drive pulley from the motor is transmitted to the pulley connected to the gearbox shaft, so that the rotation received by the $1400 \mathrm{rpm}$ gearbox will come out at $35 \mathrm{rpm}$, then from the gearbox it is transmitted using a sprocket and chain connected to the washer shaft. The porang tubers are put into the washing machine and then down to the washing process.

\section{B. Calculation on the tool}

Many factors were needed as a benchmark for the feasibility of using the machine and as a standard reference. Among them in the calculations on the tools used are: [5]

1. Force and Torque

Analysis of force and torque obtained from 4 types of experimental variations. These variations include the size of porang tubers, mass of porang tubers, and time. The formula for calculating the force used is:

$$
F_{\text {average }}=\frac{\sum F_{s}}{\sum_{\text {variation }}}
$$

As for the formula for finding torque:

$$
T=F_{\text {experimental }} \cdot r_{\text {pulley }}
$$

2. Power

Analysis of the power required on the engine using the formula:

$$
P=\frac{n}{T .9549}
$$

3. Belt and pulley

For belt planning, the selected material is rubber canvas with $=1.25 \mathrm{~kg} / \mathrm{dm} 3$ and the value of the modulus of elasticity $(\mathrm{Eb})=800 \mathrm{kgf} / \mathrm{cm} 2$

4. Shaft

Shaft resultant moment

It is necessary to make a moment plane diagram to determine the location of the resultant moment on the axis in the horizontal and vertical planes. The equations used are:

$$
M_{t}=\sqrt{\left(M_{h}\right)^{2}+\left(M_{v}\right)^{2}}
$$

Torque Shaft

To find the torque on the shaft can be used the formula:

$$
T=9.74 \times 10^{5} \frac{N_{d}}{n_{2}}
$$

5. Bearing

Equivalent Weight

Bearings receive a combined load of radial load (Fr) and axial load $(\mathrm{Fa})$, because the type of bearing selected is uniform and steady load roller bearing. For the formula used:

$P=F_{S}\left(V \cdot X \cdot F_{r}+\gamma \cdot F_{a}\right)$

As for the life of horizontal and vertical bearings can be calculated using the formula:

$L_{10}=\frac{10^{6}}{60 \cdot n_{p}} \cdot\left(\frac{C}{p}\right)^{b}$

6. Selling price of tools

To calculate the selling price of the tool, it is the accumulation of the cost of raw materials, machinery, planning, manufacture, taxes, etc. So that the appropriate selling price of the equipment is obtained and the calculation of the return on capital is obtained. Result and discussion 


\section{RESULTS AND DISCUSSION}

III.1 Force and torque analysis

TABLE 1.

SPECIFICATION OF PORANG TUBER

\begin{tabular}{|c|c|c|c|c|}
\hline \multicolumn{5}{|c|}{ SPECIFICATION OF PORANG TUBER } \\
\hline $\begin{array}{l}\text { Porang } \\
\text { Tuber }\end{array}$ & $\begin{array}{l}\text { Brush } \\
\text { mass } \\
\text { (gram) }\end{array}$ & $\begin{array}{c}\text { Porang } \\
\text { tuber } \\
\text { mass } \\
(\mathrm{kg})\end{array}$ & $\begin{array}{c}\text { Shearing } \\
\text { force } \\
\left(F_{s}\right)\end{array}$ & $\begin{array}{l}\text { Time } \\
(\mathrm{sec})\end{array}$ \\
\hline $\begin{array}{c}280 \mathrm{~mm} \mathrm{x} \\
170 \mathrm{~mm}\end{array}$ & 10500 & 6 & $29.9 \mathrm{~N}$ & 106 \\
\hline $\begin{array}{c}200 \mathrm{~mm} \mathrm{x} \\
140 \mathrm{~mm}\end{array}$ & 10500 & 3 & $12.16 \mathrm{~N}$ & 99 \\
\hline $\begin{array}{c}180 \mathrm{~mm} \mathrm{x} \\
130 \mathrm{~mm}\end{array}$ & 10500 & 2.25 & $6.9 \mathrm{~N}$ & 95 \\
\hline $\begin{array}{c}160 \mathrm{~mm} \mathrm{x} \\
80 \mathrm{~mm}\end{array}$ & 10500 & 1.05 & $2.24 \mathrm{~N}$ & 78 \\
\hline
\end{tabular}

$\mathrm{F}_{\text {average }}=12.8 \mathrm{~N}$

Total brush to sustain force $=2$

Then, experimental force :

$$
F_{p}=F_{\text {average }} \cdot z=25.6 \mathrm{~N}
$$

Total tool cleansing torque :

$$
T=F_{\text {experimental }} \cdot r_{\text {pulley }}=1920 \mathrm{~N} \cdot \mathrm{mm}
$$

Table 1 shows the specifications of the porang tuber. There are four variations of dimensions and a porang tuber, all of which have a brush mass of 10500 grams. Of the four variations, the larger the dimensions of the porang tuber, the longer the time used. This is proportional to the shearing force that occurs. In the calculation process, an average force of $12.8 \mathrm{~N}$ is used. This force will be used to calculate the experimental force and torque. From the calculation, it is found that the torque value is 1920 N.mm.

\section{III.2 Power analysis}

From calculation before, got Torque with 1,920 N.mm, engine axis rotation with $35 \mathrm{rpm}$. With power equation, obtained:

$$
\begin{gathered}
T=9549 \times \frac{P(\mathrm{~kW})}{n(r p m)} \\
P=\frac{1,920 \mathrm{kgf.mm} \times 35 \mathrm{rpm}}{9549}=0,00703 \mathrm{~kW}
\end{gathered}
$$

From the power calculation, that obtained $0,00703 \mathrm{~kW}$. But reserved motor was 2,2 HP with $1400 \mathrm{rpm}$ speed. So the engine wouldn't lack of power for running.

\section{III.3 Belt and pulley analysis}

In the belt and pulley analysis, the maximum stress is sought when running the engine. Obtained:

$$
\begin{aligned}
\sigma_{\max }=\sigma_{0}+\frac{F_{e}}{2 \cdot A} & +\frac{y \cdot v^{2}}{10 \cdot g}+E_{b} \frac{h}{D_{\min }} \\
& =82.828 \mathrm{kgf} / \mathrm{cm}^{2}
\end{aligned}
$$

\section{III.4 Selling price of tools}

The costs of expenditure in the manufacturing process can be seen in Table 2. The cost of raw materials is the most expensive cost among other costs. Other costs consist of machining costs and planning costs. From the calculation results, the total manufacturing cost is $\mathrm{Rp}$. $11,407,500$.

TABLE 2.

TABLE OF MANUFACTURING COST

\begin{tabular}{lcr}
\hline \multicolumn{1}{c}{ Name } & Units & \multicolumn{1}{c}{ Price } \\
\hline \hline Raw material cost & $\mathrm{Rp}$ & $7,150,000$ \\
Machining cost & $\mathrm{Rp}$ & 850,000 \\
Planning cost & $\mathrm{Rp}$ & 2.632 .550 \\
\hline \hline Total (manufacturing & $\mathrm{Rp}$ & $11,407,500$ \\
cost) & & \\
\hline \hline
\end{tabular}

TABLE 3.

TABLE OF SELLING PRICE

\begin{tabular}{lcr}
\hline \hline \multicolumn{1}{c}{ Name } & Units & Price \\
\hline \hline Total manufacturing cost & $\mathrm{Rp}$ & $11,407,500$ \\
profit & $\mathrm{Rp}$ & $3,422,250$ \\
Tax sales & $\mathrm{Rp}$ & $1,140,750$ \\
Fees change & $\mathrm{Rp}$ & $9.617 / \mathrm{jam}$ \\
\hline \hline Total cost & $\mathrm{Rp}$ & $17,567,550+8,500,00 . \mathrm{X}$ \\
\hline \hline
\end{tabular}

The selling price is the sum of manufacturing costs, profits, taxes and change fees. The details can be seen in Table 3. If the payback period is 5 days and 8 hours effective per day, the BEP is achieved in 228.4 days or 28.5 weeks or 7.1 months

\section{CONCLUSION}

From the planning and calculations on the porang tuber washing machine, the following data were obtained:

1. Force of $25.6 \mathrm{~N}$ and Torque of $1920 \mathrm{~N}$.mm

2. The motor power used to wash porang tubers is 2.2 HP

a. pulley Diameter $1=4$ in $=101.60 \mathrm{~mm}$

b. pulley Diameter $2=4$ in $=101.60 \mathrm{~mm}$

c. motor rotation $=1400 \mathrm{rpm}$

d. washer rotation $=35 \mathrm{rpm}$

3. Budget plan
a. Raw material cost $=$ Rp. $7,150,000$
b. Machining cost $=$ Rp. 850,000
c. Planning cost $=$ Rp. $2,632,550$
d. Manufacturing cost $=$ Rp. $11,407,500$

4. Selling price of tools
a. profit $=$ Rp. $3,422,25$
b. sales tax $=$ Rp. $1,140,750$
c. $\quad$ selling price $=$ Rp. $15,970,500$
d. fixed cost $=$ Rp. $15,970,000$
e. fees change $=$ Rp. 9.617/hour
f. total cost $=$ Rp. $17,567,550+$ Rp. $8,500,000 . X$
g. If the payback period is 5 days and 8 hours effective per day, the BEP will be achieved in 228.4 days, or 28.5 weeks or 7.1 months. 


\section{REFERENCES}

[1] Dinas kehutanan Provinsi Jawa Timur cabang wilayah Malang, "Potensi porang", Malang, 2019.

[2] Saleh, Nasir dkk, "Tanaman Porang: Pengenalan, Budidaya, dan Pemanfaatannya". Bogor: Pusat Penelitian dan Pengembangan Tanaman Porang, 2019

[3] KK Haryani Kristinah, Suharto, Suryanto, "Production of Chips of Porang (Amorphophallus Oncophyllus) by Slicing Machine with Rotating Double Cutters", International Journal of Innovative Research in Advanced Engineering (IJIRAE): pp. 2349-2763 Issue 09, Vol. 3. 2016.

[4] F. Arif, "Mekanika dan Elemen Mesin", Malang: Kementrian Pendidikan Dan Kebudayaan, 2013.

[5] J. Dewanto, B. H. Purnomo, "Pembuatan Konyaku dari Umbi Ilesiles (Amorphophallus Oncophyllus)", Universitas Sebelas Maret, Surakarta, 2009. 